\title{
Familiar Wild Flowers
}

By B. DeVRIES, Fort Qu'Appelle, Saskatchewan

No. 4 THE GOLDEN-RODS

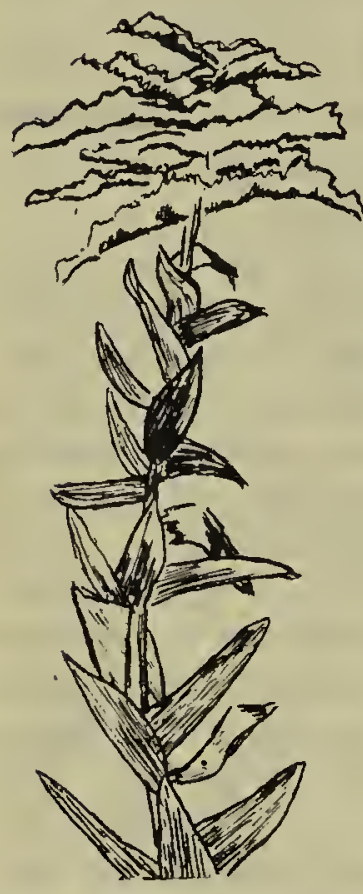

Sketch by

B. DeVries

These well known fall flowers of the genus Solidago belong to the large and varied Compositae, a family of th e Dicotyledons. $\mathrm{T}$ h e Golden - rods are perennial herbs with thickened roots. In height they range from as low as eight inches in Solidago mollis Bartl. to over three f e e $t$ in Solidago dumetorum Lunell. Usually they are unbranched or only slightly branched, with undivided toothed or entire leaves which are alternate and varied in form. Some plants have leaf stalks, for example the basal leaves of Solidago rigida L., others have stalkless leaves, for example Solidago serotina Ait.

The flower heads are numerous and small. They are borne in terminal panicles or in dense corymbose clusters. The individual heads bear many small flowers of two kinds. The central tubular or disc flowers have the task of producing seeds. The ligulate or ray flowers attract the insects for cross pollination. They are usually of a bright yellow color. Each fertile floret produces one seed in its inferior ovary. The fruits are distributed by means of a rough hairy pappus, which renders the achene light enough to be carried by the wind.

In the fall these Golden-rods give a colorful display along the roadsides and in wooded areas of our province. These flowering plants often grow with Asters for they both grow in a wide variety of soil types. They bloom from mid-summer until frost. Sometimes the tufted fruits are to be seen well into winter.

\section{Some More Interesting Cypress Hills Plants}

\author{
ARCH. C. BUDD, Swift Current, Sask.
}

In the accompanying sketch are three more plants which are peculiar in Saskatchewan to the Cypress Hills. First is the Squaw-root, Yamp or Yampa, Perideridia Gairdneri $(\mathrm{H}$. and A.) Mathias. This is a slender stemmed erect plant of the Parsley family, from one to three feet in height with umbels of tiny white flowers. The pinnate leaves bear very narrow leaflets from two to six inches long and, except for the inflorescene, the plant is not very conspicuous. The roots are fleshy and generally bear a fascicle or cluster of small, aromatic tubers. These tubers formed one of the favourite farinaceous foods of the Indians, sometimes eaten raw for their nutty flavour but more often cooked. This plant is found plentifully from the Rocky Mountains and their foothills westward to the Pacific Coast, but is found on the prairies only in the Cypress Hills. Other scientific names under which this plant has been listed include Atenia montana, Carum Gairdneri, and Carum erythrorhinum.

Occasionally, in the pine forest of the Cypress Hills one comes across a peculiar, pinkish-purple stem from one to three feet high, with small scale-like leaves. These stems are sticky and eventually bear at the top a raceme of white, urn-shaped flowers about a quarter of an inch long. These produce flattened, round capsules containing numerous seeds. This is Pine Drops, or Giant Birds' nest, Pterospora Andromedea Nutt, a saprophytic plant, one that derives its nutriments from decaying parts of other plants. Although found sparingly in ciniferous woodlands from the Atlantic to the Pacific, it 


\section{MORE INTERESTING GYPRESS PLANTS.}
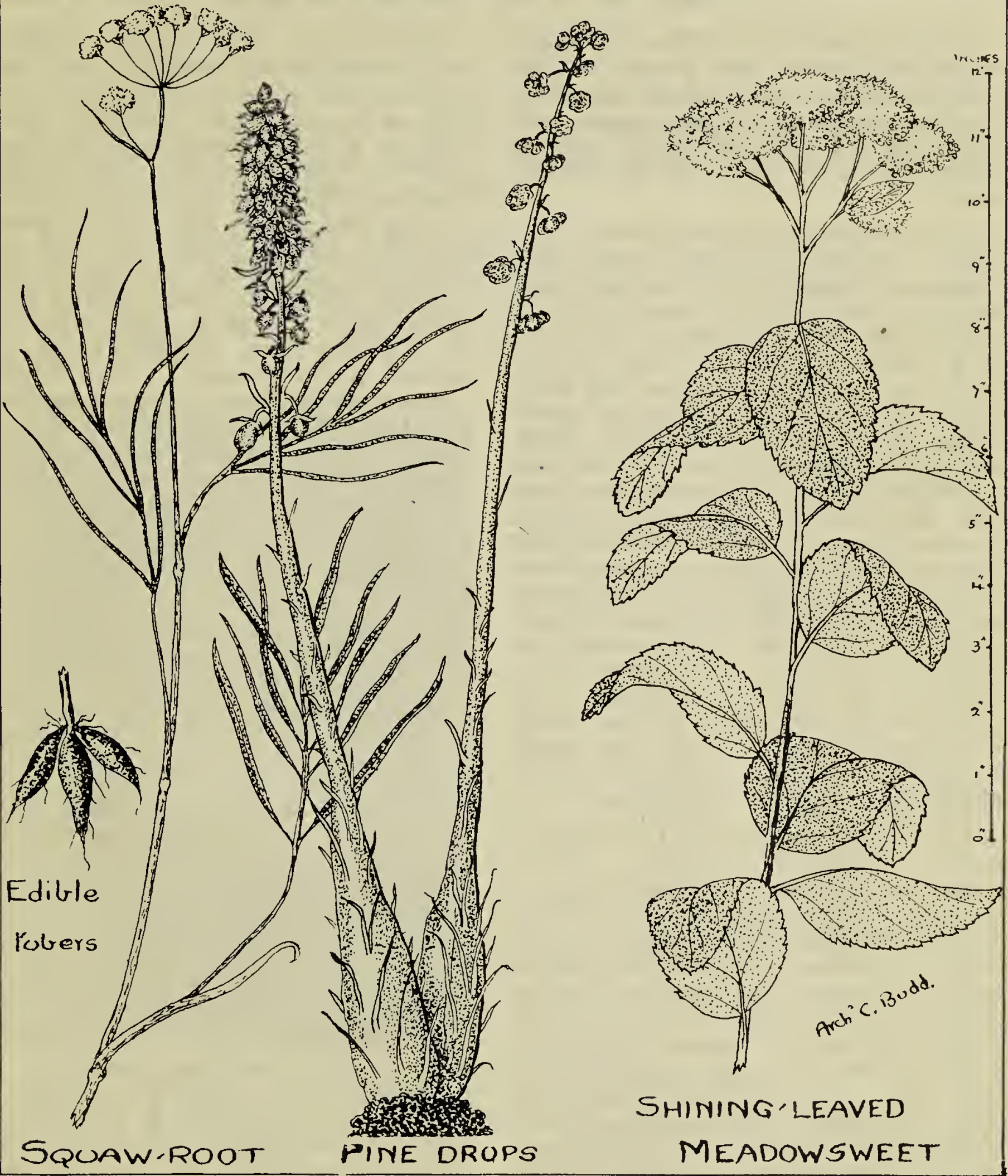

appears that the Cypress Hills remains its only location in Saskatchewan or Manitoba.

The remaining plant in the sketch is Shining-leaved Meadow - sweet, Spiraea lucida Dougl., an erect shrubby plant about two feet high. The leaves are short-stalked and oval, from one to three inches long, serrate margined towards the point, shiny-green above and glaucous and somewhat paler beneath. The in- florescence is a flat-topped corymb of whitish, small flowers, thus separating this species from our other native Spiraeas which have pyramidal panicles. This plant is quite plentiful in the Cypress Hills but not found elsewhere until the Rocky Mountain foothills are reached. From there it is found as far west as the beginning of the Cascades. Another scientific name is Spiraea betulifolia on account of its birch-like leaves. 